\title{
FUNGICIDAL EFFECT AND PHYTOTOXICITY OF SOME HERBICIDES, PLANT EXTRACTS , COMMERCIAL PLANT OILS,FUNGAL FILTRATES COMPARED WITH TEBUCONAZOLE ON SOME FUNGI AND SEEDLINGS OF COTTON AND WHEAT. \\ Kishk, E. A. A. \\ Plant Protection Department, Faculty of Agricultural, Tanta University Egypt.
}

\begin{abstract}
In this work, six plant extracts (sweet basil, peppermint, sweet scented geranium, roselle, cumin and black pepper), three commercial plant oils(nigella oil, cumin oil and castor oil), two herbicides (bentazon and clethodim), two fungal filtrates(Trichoderma harzianum and Trichoderma viride) and one fungicide (tebuconazole) were tested to control Fusarium oxysporum, Aspergillus niger and Rhizoctonia solani which cause damping-off and root rot diseases to many crops. Furthermore, the mixtures of Trichoderma viride filtrate or T. harzianum with other treatments were tested against the three fungi to study the joint action. The phytotoxicity of all treatments was tested on cotton and wheat seedlings in agar medium. The results revealed that fungicide tebuconazole was the most effective in controlling $F$. oxysporum, $A$. niger and $R$. solani under laboratorial conditions, followed by the filtrates of $T$. spp., plant oils and plant extracts, respectively. The lowest effect was observed by herbicides. The mixtures of $T$. viride or $T$. harzianum with all others treatments gave additive and synergistic effects against all tested fungi. All treatments did not show any phytotoxic effects against cotton and wheat seedlings except some treatments which gave slight phytotoxic effects .
\end{abstract}

\section{INTRODUCTION}

Recently, researchers all over the world are looking for new fungicides and other chemicals that may have harmless effects to beneficial microorganisms, insects and animals (Glagunova et al., 2008). Grinstein et al., (1984) reported that dinitroaniline herbicides applied in soil or on plant leaves caused $40-98 \%$ reduction in infection of tomato seedlings by vascular wilt-pathogen Fusarium oxysporum compared with control. Bruckart et al., (1988) mentioned that bentazon reduced rust incidince disease by $30 \%$ against Puccinia spp. at low concentration. Continues use of synthetic pesticides for plant disease control has resulted in several environmental problems such as long persistance period (Beye, 1978) pollution (Dubey and Mall, 1972), phytotoxicity (Fawatt and Spencer, 1970), teratogenicity (Javoraska, 1978) and carcinogenicity (Epstein et al., 1967). These factors require the need for new methods to control plant diseases (wilson et al., 1987). Microbial control of plant pathogens is becoming important for plant disease by using Trichoderma spp. and or Gliocladium spp. The action may be due to different mechanisms such as attacking the mycelium of pathogen or by producing toxic substances or by parasiting the hypha of pathogens and the antibiosis (Upadhyay and Makhopadhyay, 1986). Plant extracts and 
Kishk, E. A. A.

plant oils are effective and alternative sources of fungi toxic compounds showing considerable promise. These compounds generally were inhibitory to growth and spore germination of the fungi and were potent even at very low concentrations (Omer et al., 1993). Ibrahim et al.,(2004) mentioned that Trichogerma spp. and Bacillus spp. filtrates were very effective in controlling Sclerotium cepivorum Berk. Some investigators reported that plant oils and plant extracts were used as fungicides, insecticides and acaricidies (Ismail and Ahmed., 2000 , Ibrahim et al .,2005 and Lee et al ., 2005). Siddaramaiah et al., (1981) found that herbicides (Basalin, Lasso and Tak.E.25) completely inhibited the linear growth of Aspergillus niger and A. flaves in pot culture at 2000 ppm. Abdulsalam and Rezk, (1990) mentioned that Rhizoctonia solani was more susceptible to seven herbicides and insecticides than Fusarium oxysporum. EL-Khadem et al., (1984) studied the effect of some preemergence herbicides on cotton diseases caused by Fusarium oxysporum and Rhizoctonia solani. Fusarium disease incidence was reduced significantly by the higher concentrations of all herbicides, while Rhizoctonia solani disease incidence has not be significantly affected by all tested herbicides.

The aim of this work was to study: (1) The effect of different treatments in controlling Fusarium oxysporum, Aspergillus niger and Rhizoctonia solani, (2) The comparison between the effect of plant oils, plant extracts, fungal filtrates and herbicides with that of control and the fungicide tebuconazole, (3) The joint action of $T$. viride or T. harzianum with all treatments other than the fungicide tebuconazole, and (4) The phytotoxicity of all treatments on cotton and wheat seedlings.

\section{MATERIALS AND METHODS}

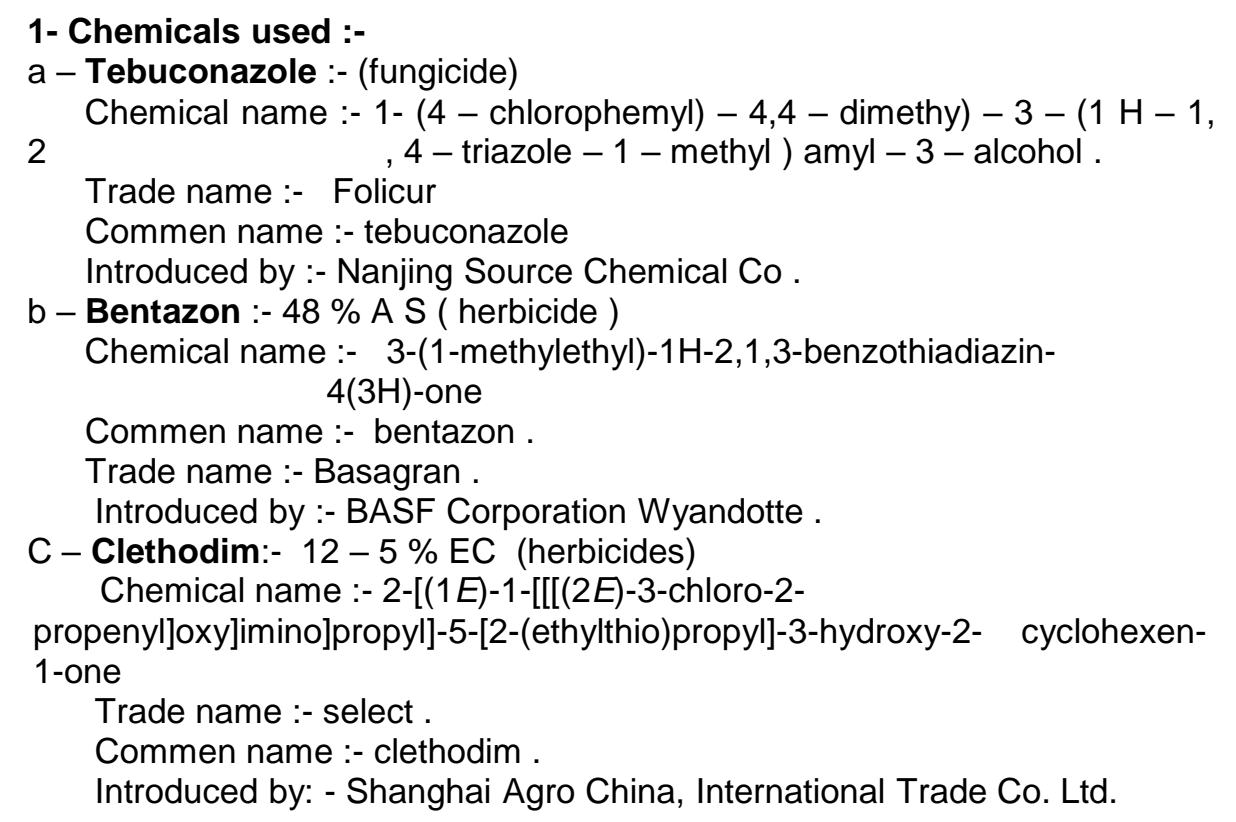


2 - Commercial plant oils:-

Table 1: plant oils used.

\begin{tabular}{|l|l|l|}
\hline No. & English name & Introduced by \\
\hline $1-$ & Nigella oil & Tanta company for oils and soap. \\
$2-$ & Cumin oil & Elkabten company for oils extracting . \\
$3-$ & Castor oil & Elkabten company for oils extracting. \\
\hline
\end{tabular}

\section{3- Plant extracts:-}

Six plants were selected, collected and identified by specialists from farm of the Faculty of Agriculture, Tanta University in Tanta as shown in Table (2).

Table (2) plant extracts used.

\begin{tabular}{|l|l|l|l|}
\hline No. & English name & Scientific name & Part used \\
\hline 1 & Sweet basil & Ocimum basilicum & Leaves \\
2 & Peppermint & Mentha viridis & Leaves \\
3 & Sweet scented geranium & Pelargonium graveolens & Leaves \\
4 & Roselle & Hibiscus sabdariffa & flowers \\
5 & Cumin & Cumim cyminum & seeds \\
6 & Black pepper & Pipper nigrum & seeds \\
\hline
\end{tabular}

\section{4- Fungal culture filtrates:-}

Two Antagonistic fungi (Trichoderma harzianum and T. viride) were obtained from the Department of Agricultural Botany, Faculty of Agriculture, Kafr El-Sheik. The two fungi were grown on liquid media of potato dextrose in $250 \mathrm{ml}$ conical flasks each containing $50 \mathrm{ml}$ media for 10 days at $28 \div \mathrm{C}$. Cultures were filtrated through cheesecloth before centrifugation for $15 \mathrm{~min}$. at 10,000 rpm to seperat the biomass (Ibrahim et al., 2004). Those filtrates were tested against Rhizoctonia solani, Aspergillus niger and Fusarium oxysporum to study their fungicidal effect and phytotoxicity on cotton and wheat seedlings.

\section{5 - Extraction procedures:-}

The leaves of sweet basil, peppermint, sweet scented geranium and flowers of roselle were dried and well grounded. Batches of $100 \mathrm{~g}$ from powdered leaves of sweet basil, peppermint, sweet scented geranium and flowers of roselle were macerated in $500 \mathrm{ml}$ of ethanol and acetone at ratio of $1: 1$ for 5 days. During the maceration periods, the samples were shaken for 5 hours using an electric shaker. Obtained extracts were filtrated, dried over anhydrous sodium sulphate and evaporated to dryness. The residue was weighed and dissolved in acetone to make the desired concentrations . Volatile oils of dry fruits of cumin and black pepper were isolated from the powder using the method described by (El-Hamady, 1989).

\section{A- Fungicidal effects:-}

1- Tested fungi were selected to study the fungicidal effect of all compounds under laboratorial conditions. These fungi were Fusarium oxysporum, Aspergillus niger and Rhizoctonia solani. The standard cultures of these 
Kishk, E. A. A.

fungi were supplied by the Department of Agricultural Botany, Faculty of Agriculture, Kafr El-Sheik.

2- Radial growth technique "in solid media" was used to test the fungicidal effect of tested compounds and combinations of fungal filtrates with herbicides, plant extracts and plant oils according to (Torgeson, 1969).

3- Medium:-

PDA medium consists of potato, dextrose and agar in $1 \mathrm{~L}$ distilled wateras final volume and then it was autoclaved at $120 \circ \mathrm{C}$ for 20 mints.

\section{4- Procedure:-}

Seven concentrations $(1,10,50,100,500,1000$, and $10000 \mathrm{ppm})$ of fungicide, plant oils, herbicides, plant extracts and fungal filtrates. A definite volume $(42 \mathrm{ml})$ of nutrient medium (PDA) at $45 . \mathrm{c}$ was mixed well with $3 \mathrm{ml}$ from each concentration of any compound to reach the total volume $(45 \mathrm{ml})$. Then the mixture of medium-compound were poured in three sterilized petridishes $(9 \mathrm{~cm}$ diameter) and considered as one treatment. In case of control, $3 \mathrm{ml}$ of distilled water add to the medium. After solidification a mycelial disc ( $5 \mathrm{~mm}$ in diameter) was taken by borer from fresh culture and located in the centre of petri-dish. All petri-dishes were incubated at $28 \pm 1$ c. Diameters of myclial growth were measured each 24 hours until the control had Just covered the plate. The percentage of inhibition $1 \%$ in the hyphal growth was calculated according to (Toppes and Wein formula, 1957) as follows:

$$
1 \%=\frac{A-B}{A} \times 100
$$

Where

I = Inhibition percentage.

$A=$ Diameter in control.

$\mathrm{B}=$ Diameter in treatment.

\section{5- Joint action:-}

The Joint action between fungal filtrates and herbicides, plant extracts, and plant oils were evaluated by following equation (Mnsoure et al., 1966)

Co-toxicity factor $=\frac{\text { Obs. }|\%-\exp .| \%}{\exp .1 \%} \times 100$

Where obs. $1 \%$ = observed $1 \%$

exp. $1 \%=$ expected $1 \%$

This factor was used to differentiate the results into three categories i.e. a positive factor of 20 or more means synergism, a negative facter of $(20$ or less) means antagonism and intermediate value $(-20$ to +20$)$ means as an additive effect. Combinations of each fungal filtrates with herbicide, plant extractes and plant oils were prepared by mixing volume containg $\mathrm{IC}_{25}$ from each fungal filtrates, and other compounds. 
B- Phytotoxic test:-

1) Test seedlings:-

Cotton (Gossypium barbadence L.) (Giza 75) and wheat (Triticum vulgar var. Giza 2) seedlings were used for testing the phytotoxic effects of the tested compounds.

2) Procedure:-

This test was carried out as described by (El-Nawawy et al., 1972). The test was accomplished by dipping seeds of cotton and wheat in water for 3-4 hours, and incubated in wet cotton cloth for $24 \mathrm{hr}$. The selected germinating seeds were placed in agar inserted in test tubes with their rootlets immersed slightly in the surface of agar containing the required concentration of each compound. Three replicates were conducted for every treatment. Test tubes were incubated in germinating room supplied with artificial light (fluoresceins) under 28-30 c. The length of the shoots and roots were measured every 24 hours for 10 days. The phytotoxic effect against shoots and roots was determined as percent of length inhibition (I \%) using the following equation:-

$1 \%=\frac{A-B}{A} \times 100$

Where, $I=$ Inhibition percent.

$A=$ Length of shoots and roots in control.

$D=$ Length of shoots and roots in treatments.

\section{RESULTS AND DISCUSSION}

\section{1-Fungicidal effect:-}

Results in Table (3) showed that the high effect was observed by filtrate of $T$. viride $\left(I C_{50}=120 \mathrm{ppm}\right), T$. harzianum $\left(I C_{50}=150 \mathrm{ppm}\right)$, extract of black pepper ( $\left.\mathrm{IC}_{50}=200 \mathrm{ppm}\right)$, extract of cumin $\left(\mathrm{IC}_{50}=250 \mathrm{ppm}\right.$ ) and nigella oil ( $\left.\mathrm{IC}_{50}=250 \mathrm{ppm}\right)$. The lowest effect were obtained by extract of sweet basil ( $I C_{50}=800 \mathrm{ppm}$ ), extract of pepper mint ( $I C_{50}=700$ $\mathrm{ppm}$ ), and both clethodim and sweet scented geranium ( $\mathrm{IC}_{50}=600 \mathrm{ppm}$ ) against Fusarium oxysporum. The effect of the tested compound against Rhizoctonia solani (Table 3) indicated that the most effective was filtrate of $T$. harzianum ( $\mathrm{IC}_{50}=180 \mathrm{ppm}$ )then $T$. viride and nigella oil ( $\mathrm{IC}_{50}=200 \mathrm{ppm}$ ) for each one, while bentazon had the lowest effect ( $\mathrm{IC}_{50}=1100 \mathrm{ppm}$ ) followed by extract of sweed scented geranium ( $\left.\mathrm{IC}_{50}=1000 \mathrm{ppm}\right)$, sweet basif $\left(I_{50}=1000 \mathrm{ppm}\right)$ and pepper mint which gave $\left(\mathrm{IC}_{50}=900 \mathrm{ppm}\right)$ against Rhizoctonia solani. Data in Table ( 3 ) also indicated that Aspergillus niger was less susceptble than the others fungi. Results showed that the most effective was obtained by $T$. harzianum $\left(\mathrm{IC}_{50}=220 \mathrm{ppm}\right), T$. viride $\left(I_{50}=250 \mathrm{ppm}\right)$, cumin oil $\left(I_{50}=250 \mathrm{ppm}\right)$ castor oil $\left(I_{50}=300 \mathrm{ppm}\right)$, bentazon $\left(I_{50}=320 \mathrm{ppm}\right)$, and nigella oil $\left(\mathrm{IC}_{50}=350 \mathrm{ppm}\right)$. Data present in table 3 , also, indicated That extract of peppermint gave the lowest effect 
Kishk, E. A. A.

$\left(\mathrm{IC}_{50}=3000 \mathrm{ppm}\right)$ followed by sweet basil extract $\left(\mathrm{IC}_{50}=2000 \mathrm{ppm}\right)$ and clethodim $\left(\mathrm{IC}_{50}=2000 \mathrm{ppm}\right)$.In all cases the effect of all tested compounds were less than the effect of fungicides tebuconazole which gave $\left(\mathrm{IC}_{50}=6\right.$, 10 and 30) ppm against Fusarium oxysporum, Rhizoctonia solani and Aspergillus niger respectively. These results were in full agreement with the findings of (Zein et al ; 1984 , Ibrahim et al ; 2004 and lbrahim et al ; 2005). The high effect of fungal filtrates, may be , return to its containing antibiotic where Bilai (1963) reported that $T$ spp . secrete antibiotic "gliotoxin" . Plant oils were effective against tested fungi also, may be, due to its contact effect or physical toxicity. Oils dissolve in lipids and fats and therefore oils penetrate the cell membrane of fungi and affect as contact poisons or destroy the balance between oil-water contents inside cells (Green et al., 1989). Plant extracts contain one or more from these compounds :- alkaloids , glycosides, tannins, bitter agents, colouring agents, volatile oils and fixed oils. The fungicidal effect of plant extract, may be, returns to these compounds.

Table ( 3 ): Fungicidal effect of herbicides, plant extracts, plant oils and fungal filtrates compared with tebucomozle against Fusarium oxysporum, Rhizoctonia solani and Aspergillus niger by using radial growth technique $\left(\mathrm{IC}_{50}\right.$ and $\left(C_{25}\right)$.

\begin{tabular}{|c|c|c|c|c|c|c|c|c|c|}
\hline \multirow[t]{2}{*}{$\begin{array}{l}\text { Fungus } \\
\text { treatment }\end{array}$} & \multicolumn{3}{|c|}{$\begin{array}{c}\text { Fusarium } \\
\text { oxysporum }\end{array}$} & \multicolumn{3}{|c|}{$\begin{array}{c}\text { Rhizoctonia } \\
\text { solani }\end{array}$} & \multicolumn{3}{|c|}{$\begin{array}{c}\text { Aspergillus } \\
\text { niger }\end{array}$} \\
\hline & $\mathrm{IC}_{25}$ & $\mathrm{IC}_{25}$ & slope & $\mathrm{IC}_{25}$ & $\mathrm{IC}_{25}$ & slope & $I_{25}$ & $\mathrm{IC}_{25}$ & slope \\
\hline Herbicides & & & & & & & & & \\
\hline Clethodim & 20 & 600 & 0.53 & 05 & 350 & 0.35 & 40 & 2000 & 0.33 \\
\hline $\begin{array}{l}\text { Bentazon } \\
\text { Plant oil }\end{array}$ & 3.5 & 350 & 0.35 & 30 & 1100 & 0.36 & 43 & 320 & 0.60 \\
\hline Nigella oil & 04 & 250 & 0.35 & 03 & 200 & 0.32 & 12 & 350 & 0.49 \\
\hline Comin oil & 10 & 320 & 0.43 & 12 & 350 & 0.52 & 04 & 250 & 0.33 \\
\hline $\begin{array}{l}\text { Castor oil } \\
\text { Plant extracts }\end{array}$ & 12 & 400 & 0.48 & 40 & 320 & 0.60 & 08 & 300 & 0.43 \\
\hline Sweet basil & 25 & 800 & 0.24 & 08 & 1000 & 0.30 & 120 & 2000 & 0.47 \\
\hline Peppermint & 40 & 700 & 0.50 & 20 & 900 & 0.32 & 150 & 3000 & 0.43 \\
\hline $\begin{array}{l}\text { Sweet scented } \\
\text { geranium }\end{array}$ & 20 & 600 & 0.40 & 25 & 1000 & 0.34 & 80 & 1500 & 0.44 \\
\hline Roselle & 15 & 420 & 0.48 & 20 & 320 & 0.50 & 13 & 510 & 0.38 \\
\hline Cumin & 12 & 250 & 0.45 & 10 & 300 & 0.46 & 80 & 720 & 0.65 \\
\hline $\begin{array}{l}\text { black pepper } \\
\text { Fungal filtrate }\end{array}$ & 09 & 200 & 0.43 & 8 & 270 & 0.42 & 12 & 630 & 0.48 \\
\hline T. viride & 6 & 120 & 0.46 & 22 & 200 & 0.58 & 11 & 250 & 0.55 \\
\hline $\begin{array}{l}\text { T. harzianum } \\
\text { Funqicide }\end{array}$ & 30 & 150 & 0.60 & 09 & 180 & 0.43 & 14 & 220 & 0.34 \\
\hline Tebuconazle & 0.9 & 06 & 0.75 & 02 & 10 & 0.86 & 9 & 30 & 0.98 \\
\hline
\end{tabular}

\section{2- Joint action:-}

Results in Table (4) indicated that combinations of $T$. viride filtrate with both clethodim , cumin oil, Roselle extract, cumin extract, and black 
pepper gave synergistic effects where Co- toxicity factor were $(22.2,26.4$, $22.6,22.8$ and 32.2) against Fusarium oxysporum while other combinations gave additive effects, when the Pairs mixed by $\mathrm{IC}_{25}$ of each. The Pairs of $T$. viride against Rhizoctonia solani with bentazon, nigella oil and peppermint extract gave synergistic effects (20.2, 22.6 and 20.8), respectively. The combination of $T$. viride filtrate with all compounds did not give synergistic effects when tested against Aspergillus niger. The other combinations had additive effects positive or negative.

Table (4:) Interaction effect between filtrate of $T$. viride with herbicides, plant extracts and plant oils against Fusarium oxysporum, Rhizoctonia solani and Aspergillus niger by using radial growth technique (Co-toxicity factor)

\begin{tabular}{|c|c|c|c|c|c|c|}
\hline \multirow{2}{*}{ Treatment } & \multicolumn{2}{|c|}{$\begin{array}{l}\text { Fusarium } \\
\text { oxysporum }\end{array}$} & \multicolumn{2}{|c|}{$\begin{array}{l}\text { Rhizoctonia } \\
\text { solani }\end{array}$} & \multicolumn{2}{|c|}{$\begin{array}{c}\text { Aspergillus } \\
\text { niger }\end{array}$} \\
\hline & obs . I \% & C.T.F & obs $1 \%$ & C.T.F & obs $1 \%$ & C.T.F \\
\hline Herbicides :- & & & & & & \\
\hline 1- Bentazon $+T_{1}$ & 58.2 & 16.4 & 60.1 & 20.2 & 54.2 & 08.4 \\
\hline $\begin{array}{l}\text { 2- Clethodim }+\mathrm{T}_{1} \\
\text { Plant oils :- }\end{array}$ & 61.1 & 22.2 & 5.7 .5 & 15.0 & 55.3 & 10.6 \\
\hline 1 - Nigella oil $+T_{1}$ & 55.3 & 0.6 & 61.3 & 22.6 & 56.3 & 12.6 \\
\hline 2- Cumin oil $+T_{1}$ & 63.2 & 26.4 & 53.8 & 07.6 & 58.4 & 16.8 \\
\hline $\begin{array}{l}\text { 3- Castor oil }+\mathrm{T}_{1} \\
\text { Plant extracts :- }\end{array}$ & 54.4 & 8.8 & 52.7 & 05.4 & 51.6 & 03.6 \\
\hline 1 - Sweet basil $+T_{1}$ & 53.2 & 6.4 & 52.3 & 04.6 & 48.2 & -3.6 \\
\hline 2- Peppermint $+T_{1}$ & 57.7 & 15.4 & 60.4 & 20.8 & 45.3 & -9.4 \\
\hline $\begin{array}{l}\text { 3- Sweet scented } \\
\text { geranium }+T_{1}\end{array}$ & 52.5 & 05 & 55.4 & 10.8 & 42.6 & -14.8 \\
\hline 4- Roselle $+T_{1}$ & 61.3 & 22.6 & 56.2 & 12.4 & 52.6 & 5.2 \\
\hline 5- Cumin $+T_{1}$ & 62.4 & 22.8 & 53.6 & 07.2 & 53.2 & 6.4 \\
\hline 6- Black pepper $+T_{1}$ & 66.1 & 32.2 & 58.2 & 16.4 & 55.4 & 10.8 \\
\hline
\end{tabular}

Where C.T.F = Co-toxicity factor

obs. $1 \%=$ observed inhibition percent .

$\mathrm{T}_{1}=T$. viride

Results presented in Table (5) indicated that the combinations of $T$. harzianum filtrate with both castor oil Roselle extract, cumin extract and black pepper gave synergistic effects where C.T.F were 20.4, 22.6 , 20.4 and 24.6 respoctively against Fusarium oxysporum, while the combinations of $T$. harzianum with bentazon and nigella oil gave synergistic effect against Rhizoctonia solani ( C.T.F was 24.4 and 26.4 , respectivily .

In case of Aspergillus niger, the combinations of $T$. harzianum filtrate with clethodim, cumin oil and cumin extract gave synergistic effect (C.T.F were 22.6, 20.4 and 22.4). The other combinations gave additive effects.

Many investigators evaluated the joint action against fungi (Zein et al., 1984 , Ismail and Ahmed .,2000) . Combination of T. viride or $T$. harzianum with plant oils, plant extracts and herbicides increased the fungicidal effect, may be , because of the combination produce new compound more toxic than each compound alone or because the first agent help the second in its pearmability and penetration the fungal cell. 
Kishk, E. A. A.

Table (5): Interaction effect between filtrate of $T$. harzianum with herbicides, plant extracts and plant oils against Fusarium oxysporum, Rhizoctonia solani and Aspergillus niger by using radial growth technique (Co-toxicity factor).

\begin{tabular}{|c|c|c|c|c|c|c|}
\hline \multirow{2}{*}{ Treatment } & \multicolumn{2}{|c|}{$\begin{array}{c}\text { Fusarium } \\
\text { oxysporum }\end{array}$} & \multicolumn{2}{|c|}{$\begin{array}{c}\text { Rhizoctonia } \\
\text { solani }\end{array}$} & \multicolumn{2}{|c|}{$\begin{array}{c}\text { Aspergillus } \\
\text { niger }\end{array}$} \\
\hline & obs. 1\% & C.T.F & obs $1 \%$ & C.T.F & obs $1 \%$ & C.T.F \\
\hline \multicolumn{7}{|c|}{\begin{tabular}{|l|l|} 
Herbicides :- & \\
\end{tabular}} \\
\hline 1 - Bentazon & 57.3 & 14.6 & 62.2 & 24.4 & 57.3 & 08.4 \\
\hline $\begin{array}{l}\text { 2- Clethodim } \\
\text { Plant oils :- }\end{array}$ & 55.4 & 10.8 & 58.2 & 16.4 & 61.8 & 23.6 \\
\hline 1- Nigella oil & 55.3 & 10.6 & 63.2 & 26.4 & 55.2 & 10.4 \\
\hline 2- Cumin oil & 58.2 & 16.4 & 51.6 & 02.6 & 60.2 & 20.4 \\
\hline $\begin{array}{l}\text { 3- Castor oil }+\mathrm{T}_{2} \\
\text { Plant extracts :- }\end{array}$ & 60.2 & 20.4 & 53.4 & 06.8 & 52.7 & 05.4 \\
\hline 1 - Sweet basil $+T_{2}$ & 52.6 & 5.2 & 53.8 & 07.6 & 52.3 & 04.6 \\
\hline 2- Peppermint $+T_{2}$ & 54.2 & 08.4 & 58.7 & 17.4 & 51.6 & 03.2 \\
\hline 3- Sweet scented & 57.7 & 15.4 & 57.2 & 14.4 & 50.5 & 01.0 \\
\hline geranium $\quad+T_{2}$ & & & & & & \\
\hline 4- Roselle & 61.3 & 22.6 & 53.8 & 07.6 & 57.3 & 14.6 \\
\hline 5- Cumin $\quad+T_{2}$ & 60.2 & 20.4 & 55.7 & 11.4 & 61.2 & $22 . .4$ \\
\hline 6- Black pepper $+T_{2}$ & 62.3 & 24.6 & 56.6 & 13.2 & 58.2 & 16.4 \\
\hline
\end{tabular}

Where $\mathrm{T}_{2}=T$. harzianum

\section{3-Phytotoxic effect :-}

Result present in Table (6) indicated that all treatments did not give phytotoxic effect on root and shoot system of both cotton and wheat seedlings. Roselle extract has slight effect with $\mathrm{EC}_{50}$ values $(700 \mathrm{ppm})$ and (750 ppm) on root and shoot systems of cotton seedlings followed by cumin extract $(700,800 \mathrm{ppm})$ black pepper $(800,900 \mathrm{ppm})$ and bentazone $(900$, $1000 \mathrm{ppm}$ ) on root and shoot system of cotton seedlings respectively. In the other hand, all treatments were weakly in their effects on root and shoot systems of wheat seedlings except clethodim and black pepper extract with $\mathrm{EC}_{50}$ values $(800,900 \mathrm{ppm})$ for clethodim on root and shoot system of wheat seedling and by $(900,1000 \mathrm{ppm})$ for black pepper on the root and shoot system .These mean that all treatments can be used safely without any phytotoxic effects on cotton and wheat seedlings. The slight effects of oils , may be, return to its contact effect . while plant extracts caused slight phytotoxic effects due to its chemical components. Herbicides, may be, caused its effects due to its selectivity. 
Table (6): Phototoxic effect of herbicides, plant extracts, plant oils and fungal filtrates on cotton and wheat seedlings $\left(E C_{50}\right)$.

\begin{tabular}{|l|c|c|c|c|}
\hline \multicolumn{2}{|c|}{ seedlings } & \multicolumn{2}{|c|}{ Cotton seedling } & \multicolumn{2}{c|}{ Wheat seedlings } \\
\cline { 2 - 5 } Treatments & root & shoot & root & shoot \\
\hline Herbicides :- & 900 & 1000 & 1500 & 1600 \\
\hline 1- Bentazon & 1600 & 1800 & 800 & 900 \\
2- Clethodim & & & & \\
Plant oils :- & 1200 & 1100 & $>2000$ & $>2000$ \\
\hline 1- Nigella oil & 950 & 1000 & $>2000$ & $>2000$ \\
2- Cumin oil & 1000 & 1300 & $>2000$ & $>2000$ \\
3- Castor oil & & & & \\
Plant extracts :- & 1200 & 1250 & $>1500$ & $>2000$ \\
\hline 1- Sweet basil & 1300 & 1350 & $>1500$ & $>2000$ \\
2- Peppermint & 1200 & 1300 & $>2000$ & $>2000$ \\
3- Sweet scented geranium & 700 & 750 & 1000 & 1000 \\
4- Roselle & 700 & 800 & 1000 & 1200 \\
5- Cumin & 800 & 900 & 900 & 1000 \\
6- Black pepper & & & & \\
Fungal filtrate:- & $>1500$ & $>1500$ & $>1500$ & $>1500$ \\
\hline T. viride & $>1500$ & $>1500$ & $>1500$ & $>1500$ \\
\hline T. harzianum & & & & \\
\hline
\end{tabular}

REFERENCES

Abdulsalam , K.S.,M. A. Rezk (1990). Non target activity of certain pesticides against soil borne fungi. Annals of Agricultural Science (Cairo). 35 (1) : 459-467.

Beye, F. (1978). Insecticides from the vegetable Kingdom PI . Res . Dev ., 7:13-31.

Bilai , V.I. (1963) . Antibiotic-producing microscopic fungi . Elsevier Publishing Company . Amesterdam, Netherland .

Bruckart, W.L.; D.R. Jonson and J.R Frank (1988). Bentazone reduce rust induced disease in yellow nutsedge, Cyperus esculentus. Weed Technol. 2:299-303.

Dubey, R.C. and R.S. Mall (1972). Fungitoxic properties of some plant extract against vegetative growth and sclerotial viability of Macrophomina phaseolina. Indiana. Phytopathology . 44(3):411-413.

El-Hamady, Sh. E.I. (1989). Studies of natural pesticides from plants . PhD . Thesis . fac. Agric. Tanta. Uni.

EL - Khadem , M., M.K. EL Kazzaz and M. A. Hassan ( 1984 ) . Influence of different pre emergence herbicides on cotton diseases caused by $R$. Solani and F. oxysporum. Plant Soil 79 (1) : 29-36.

El-Nawawy, A.S; S.A. Abu-Donia , A.T. El-Din and E.A. kadous (1972). Relation between chemical structure and biological activity . Alex. j. agric. Res. 20(1):151-155.

Epstein , S.S .; Andreae ; H . Jaffec ; S. Joshu ; H. Folk and N. Natnel ( 1967 ) . Carcinogenicity of the herbicide meleic hydrazide. Nature , $215: 1388-1390$. 
Kishk, E. A. A.

Fawatt, C. H. and D. M. Spencer ( 1970 ) . Plant chemotherapy with natural products . A . Rev . Phytopatho ., 8:403-418 .

Glagunova, S.A. V.A. Karavaev, O.I. Pokrovskiy, O.O. Parenago (2008). Supercritical fluid extract of reynoutria sachalinensis as an environmentl benign agriculture chemical. $2^{\text {nd }}$ international IUBAC Con. on green chemistry, 14-19 Sep. 2008, Russia .

Green, M. B. ; G. S. Hartly; T. F. West (1989). Chemicals for crop improvement and pest management. Text book, third edition. Pergamon. Headington Hill Hall. Oxford OX3 OBW, England.

Grinstein, A.; N. Lisker; J. Karan and Y. Eshel (1984). Herbicides induced resistance to plant wilt disease . Physiol . Plant pathol., 24:347-356.

Ibrahim , A.S. ; D.M. Nammur and Randa Ahmed Suleiman (2005). Importane of some plant extracts in controlling acarids damaging crops . Tishreen Uni. Journal for studies and scientific Research . Biological Sciences Vol (27) NO. (2) (2005).

Ibrahim , M.E.K. ; SH. M.A. El-gremi ; M.M.E. El-Naggar and Nagwa M.M. ElKhateeb(2004). Biological control of Sclerotium cepivorum (BERK) at El-Gharbia governorate ,Egypt. J. Agric.Res.Tanta Univ.,30(3)2004.

Ismail, A.A. and F.A.M. Ahmed ( 2000 ) Antifungal activities of some plant extracts on damping - off and root-rot diseasea of cottot seedlings .J. Agric.Res. Tanta Univ., 26(4) : 728-738.

Javoraska, T. ( 1978 ) . Effect of combined herbicides on the occurrence of morphoses in the spikes of spikes of spring barley. Agrochemia, 18:37-42 .

Lee, K; S. Chang and C. Chung (2005). Effectiveness of bionatral on control of two spotted spider mites, aphids and whiteflies. Journal of the Koreansociety for Horticulture Science . 46(4):241-245.

Mansour, N.A.; El-Defrawi ; A. Toppozada and M. Zeid ( 1966 ): Toxicological studies on the Egyptian cotton leaf warm P.lilura VI . Potentiation and antagonism of organophosphorus and carbamate insecticides . J . Econ . Entomol . 49,307-311.

Omar, S.A.M.; M.M.H. Rahhal ; A.A. Hilal and A.Zayed ( 1993 ) Influence of intercropping of broad been with some medicinal plants on disease severity of chocolate spot and rust and seed yield . $4^{\text {th }}$ Conf . Agric Dev . Res . Ain-Shams Univ . , Cairo, Feb . 13-18.

Siddaramaiah, A. L. ; S. A. Desal and R. K. Hedge ( 1981 ). Effect of few herbicides on crown rot $(A$. niger $)$ and alfa rot ( $A$. flavus ) disease of groundnut Mysore J. Agric . Sci . 15 (1) : 44-47 .

Topps , J. H and R.L. Wain (1957). Investigation on fungicides. III. The fungitoxicity of 3- and 5- allegl salicylanilide and pavachlovanilines . Ann. Appl. Boil. 45(3), 506-511.

Torgeson, D. C (1969). Fungicides, vol. I. Agricultur - al and Indusricel applications Environmental Interactions. Academic Press, New Yourk , and London , P.93 .

Upadhyay , J.P . and A.N. Makhopadhyay ( 1986 ) . Biological control of Sclerotium rolfsii by Trichoderma harzianum in sugar beet. Trop pest Mgmt., 32 : 215-220. 
Wilson , Ch . ; J.D. Fanklin and B.E. Otto (1987). Fruit volatives inhibitory to Monilinia frueticola and Botrytis cinerea. Plant Dis ., 71 (4) : 316-319.

Zein, A.A; M.A.A. Ashry; A.S.EI-Nawawy and A.I. Anter (1984). The influence of some herbicides on the fungal action of some fungicides. J. Agric. Res. Tanta Uni. 10(4) 1984.

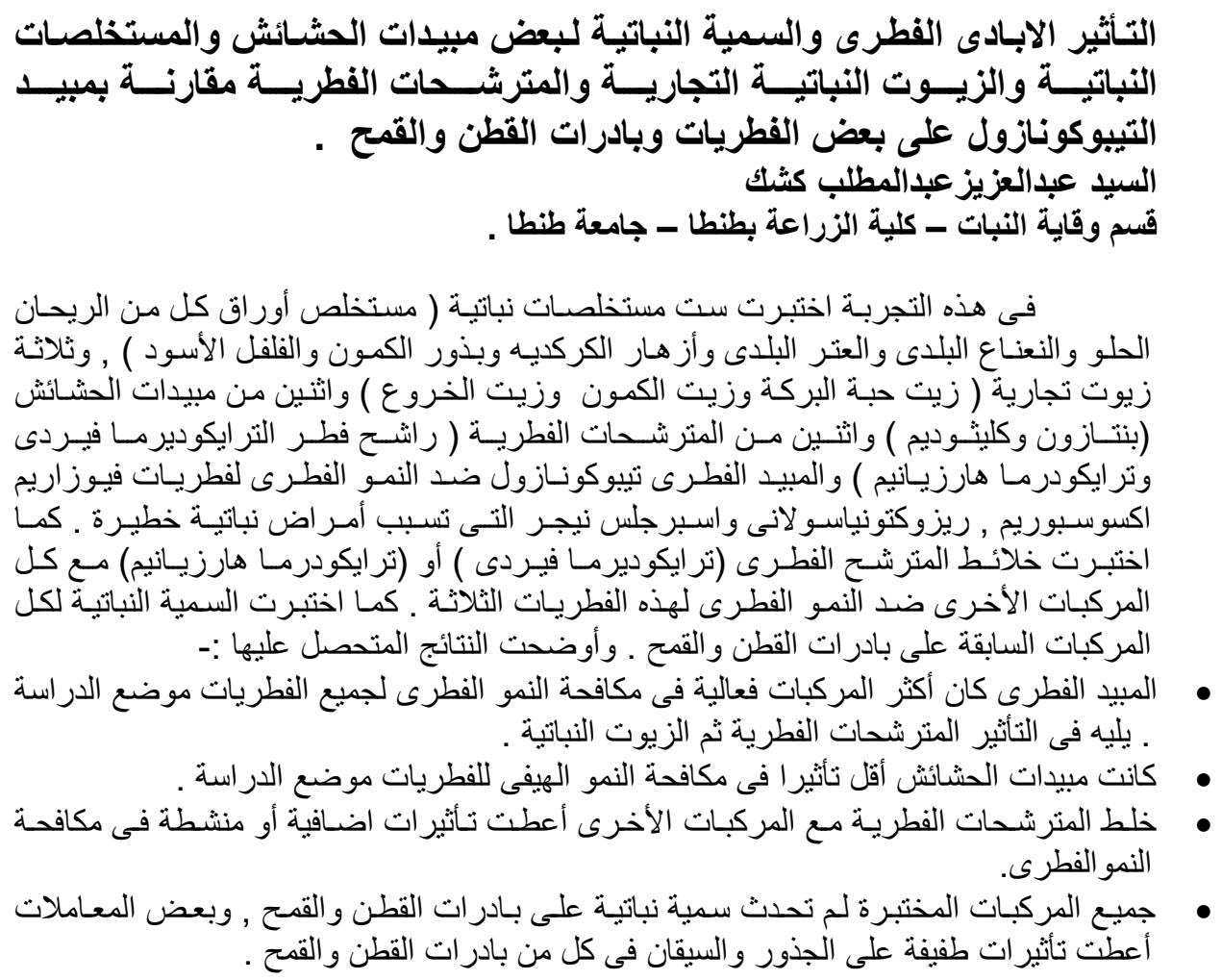

